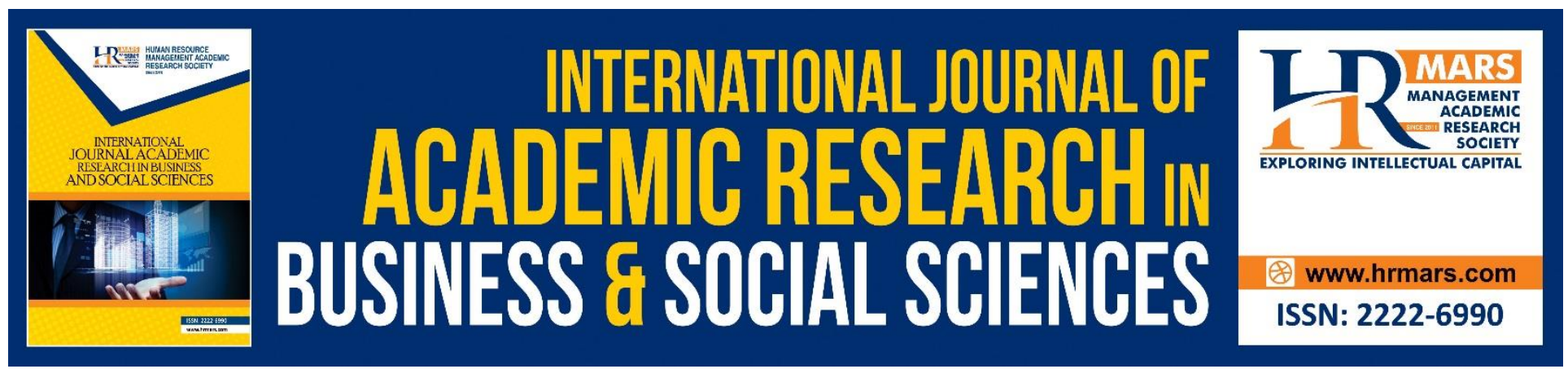

\title{
Design of Teaching Influences the Training Transfer Amongst TVET's Instructors: Fuzzy Delphi Technique
}

Syamsiah Mokhtar, Ruhizan Muhamad Yasin

To Link this Article: http://dx.doi.org/10.6007/IJARBSS/v8-i6/4303

DOI: $\quad 10.6007 /$ IJARBSS/v8-i6/4303

Received: 24 May 2018, Revised: 19 June 2018, Accepted: 29 June 2018

Published Online: 08 July 2018

In-Text Citation: (Mokhtar \& Yasin, 2018)

To Cite this Article: Mokhtar, S., \& Yasin, R. M. (2018). Design of Teaching Influences the Training Transfer Amongst TVET's Instructors: Fuzzy Delphi Technique. International Journal of Academic Research in Business and Social Sciences, 8(6), 1083-1097.

Copyright: (C) 2018 The Author(s)

Published by Human Resource Management Academic Research Society (www.hrmars.com)

This article is published under the Creative Commons Attribution (CC BY 4.0) license. Anyone may reproduce, distribute, translate and create derivative works of this article (for both commercial and non-commercial purposes), subject to full attribution to the original publication and authors. The full terms of this license may be seen

at: http://creativecommons.org/licences/by/4.0/legalcode

Vol. 8, No. 6, June 2018, Pg. 1083 - 1097

http://hrmars.com/index.php/pages/detail/IJARBSS

JOURNAL HOMEPAGE

Full Terms \& Conditions of access and use can be found at http://hrmars.com/index.php/pages/detail/publication-ethics 


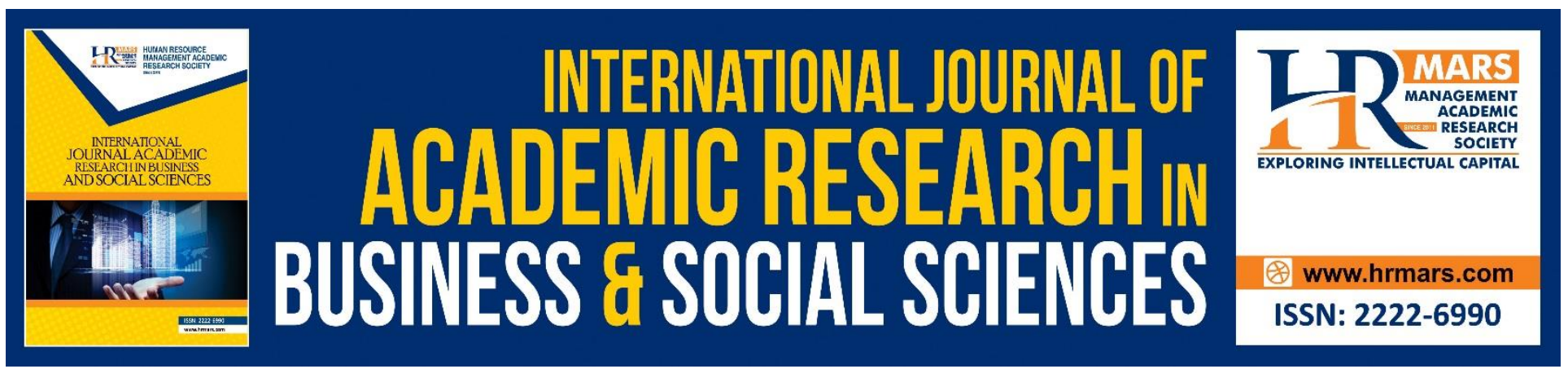

\title{
Design of Teaching Influences the Training Transfer Amongst TVET's Instructors: Fuzzy Delphi Technique
}

\author{
Syamsiah Mokhtar, Ruhizan Muhamad Yasin \\ Faculty of Education, National University of Malaysia, Malaysia
}

\begin{abstract}
Transfer of training is "transferring" the knowledge and skills acquired by instructors in training sessions applied to the workplace. Hence, this study aims to look at the views and agreements of experts on the need for elements of transfer of technical and vocational trainers training. This study is a quantitative study. The approach used to collect the research data is to use a questionnaire instrument that will be given to the expert. The number of experts involved is 13 experts. There are two criteria in the expert's determination, that they are comprised of business management lecturers who have served more than 15 years and have been directly involved with the final teaching of the final project course. All data collected were analyzed using Fuzzy Delphi Method. The findings show that all training transfer elements consisting of training designs, the threshold value is less than 0.2 and the percentage of expert groups is over $75 \%$. This shows that the design elements of the training and all the items contained therein are required by the Vocational College business management instructors based on expert agreement.
\end{abstract}

Keywords: Fuzzy Delphi Technique, Training Design, Training Transfer, Technical and Vocational Training.

\section{Introduction}

The training design is one of the design factors of a program consisting of the validity of training content, the personal capacity for transfer and the opportunity of instructors using training in the context of work (Faizal \& Ruhizan, 2016). Therefore, the failure of the training design preparation will result in the transfer of the training ineffective. Therefore, Pang (2014) explains that the existing skills development program and training programs need to be re-evaluated and strengthened to ensure the supply of skilled workers issued by all skills training agencies in the country meet the domestic and foreign job market requirements. This is necessary in ensuring that learning outcomes in the skills training institution can be practiced or used optimally in the work environment. Developing a highly skilled human resource has become the main agenda of the country in ensuring the country to become a high-income nation by the year 2020 (Nor Mohamed Yakcop, 2012). In order to realize this goal, the government has provided a great fund to the Public Skills Training Institute (ILKA) to produce highly skilled workforce through training programs or programs. This is evidenced by the government's investment in PLTV's training sector of RM8.8 billion in 2010, RM774 million in 2011, 
INTERNATIONAL JOURNAL OF ACADEMIC RESEARCH IN BUSINESS AND SOCIAL SCIENCES

Vol. 8, No. 6, June 2018, E-ISSN: 2222-6990 C 2018 HRMARS

RM520 million in 2012 and 3.7 billion in 2013 to be utilized by the skills training institute, loan preparation and ministry's operations in improving skills and productivity the workforce (Mohd Najib Abdul Razak, 2011; Mohd Najib Abdul Razak, 2010, 2012).

\section{Problem Statement}

Problems such as lack of co-operative industry, incompetent instructors, and quality of curriculum have to do with transfer of training through design factors that emphasize the design of training transfers (Azmi et al., 2010; Jalilah Wahidin, 2008). The transfer of the training becomes more critical when only a few are learned in the training program can be transferred to work to meet the organization's objective requirements (Azmi et al., 2010; Shahril Baharim, 2008). As such, this problem also exists for specialized KV teachers for business management programs.

\section{Research Objective}

The purpose of this study is to obtain an expert agreement on the factors affecting the transfer of training among the instructors.

\section{Study Questions}

Is there an expert agreement on the factors affecting the transfer of training among instructors?

\section{Literature Review}

From the review of the literature found that there are some gaps in each training transfer study in Malaysia (Azmi, 2011; Azmi et al., 2010; Pang et al., 2009; Paul, 2008). Among them is the study of the transfer of training in Malaysia is still low (Dayang Nailul Munna \& Suring, 2011). Clearly stated by Azmi (2011), there are not many studies involving the transfer of training to skills training. This is because most studies are more focused on training programs for public services.

The training design refers to the learning principles and training content that takes into account the training objectives, the materials used in training and the training content rules (Dayang Nailul Munna \& Suring, 2011). Therefore, the failure of the training design preparation results in ineffective transfer of learning. This supported the findings of the study that training designs and facilities have been found to have significant influence on transferring training (Baldwin \& Ford, 1988; Blume et al., 2010; Burke \& Hutchins 2007; Dayang Nailul Munna \& Suring, 2011; Holton 1996; Hutchins 2009 ; Lim \& Morris, 2006). Lim and Morris (2006) and Holton (1996) emphasize the effectiveness of designing training methods capable of providing trainees at a certain level of knowledge and skills. Therefore, organizations need to design training programs that provide trainers with relevant knowledge and skills.

Based on previous studies, there are various factors that can represent the design's design factors. Baldwin and Ford (1988) list three factors such as learning principles, sequences and training content. Whereas Holton et al. (2000) lists more comprehensive and comprehensive by listing four factors such as content validity, transfer design, personal capacity for transfer and opportunity to use. There are also several other factors such as learning content and material use in the work environment (Burke \& Hutchins, 2007; Yamnill \& Mclean, 2005), learning methods and strategies (Holladay \& Quinones, 2003; Machin \& Fogarty, 2004) new in work (Holton et al., 2000; Velada et al., 2007). 
INTERNATIONAL JOURNAL OF ACADEMIC RESEARCH IN BUSINESS AND SOCIAL SCIENCES

Vol. 8, No. 6, June 2018, E-ISSN: 2222-6990 ㄷ 2018 HRMARS

The literature review also found that the transfer ability factor had a positive impact in the transfer of learning through the improvement of individual performance in doing work (Holton et al., 2000; Holton, 2005). Through this factor, the trainee has the opportunity to apply learning outcomes to the workplace through control of time, energy and emotional trainer (Holton et al. 2000). Support for this factor has been proven through past studies through the testing of these factors through the testing of LTSI instruments carried out through several countries which have a significant effect on transfer of learning (Bates et al., 2007 et Coetee et al., 2006; Devos et al., 2007; Velada et al., 2009).

This transfer design factor also has a significant impact as this factor ensures that the training program developed is clear with the performance of the work through the use of clear examples, the same method as the work environment and the activities and exercises carried out are clearly at the demonstration to apply knowledge and skills at work (Coetsee et al., 2006; Holton et al., 2000). Trainers can have the opportunity to apply the knowledge and skills learned learned from clearly designed training and can link learning to work performance through clear use of examples, methods similar to the work environment, and clear activities and training.

There are several factors that can represent the design of this transfer. Among them are inputs from teacher and supervisor experience (Devos et al., 2007), equipment facilities (Burke \& Baldwin, 1999; Coetsee et al., 2006), work-related training programs (Devos et al., 2007). Devos et al. (2007) describes the help of instructors as necessary through the delivery of various examples to trainees to use learning outcomes in work and make trainers feel confident. It is also parallel to Burke and Hutchins (2007), where instructors' actions in diversifying learning strategies and methods can help trainees to easily understand a work process. It is important that trainers train themselves to diversify learning outcomes to workplace more easily. This finding is important because these factors can be controlled and related to individual factors (Devos et al., 2007). In addition, the role of the instructor is also important in ensuring the level of motivation of the trainee is at its highest level.

\section{Methodology}

This study used Fuzzy Delphi method and purposive sampling method. Hasson, Keeney and McKenna (2000) argue that the appropriate sampling method in FDM technique is non probability sampling whether it uses purposive or Criterion sampling. This method is selected as the sample is not randomly selected and it is not representative (representativeness), and it is chosen based on the purpose of looking at their knowledge and experience in depth to the field studied. This view is supported by Noraini (2010), he stated that this sampling was also known as judgment sampling because it would involve the individual's consideration of selecting a sample of research based on researcher's knowledge and research needs.

\section{Respondents and Sampling}

To evaluate the model, the researcher will use 13 field experts to evaluate the usability of the model. According to Berliner (2004), lecturers with more than five years of experience are classified as experts who have experience of teaching and managing continuously. According to Ridhuan and colleagues (2014) states that in the fuzzy Delphi method involving the development of a model, the process of obtaining agreement and expert opinion is necessary. Researchers may also use other methods such as the Partial Least Square (PLS-SEM) method to see the relationship of constructs and 
INTERNATIONAL JOURNAL OF ACADEMIC RESEARCH IN BUSINESS AND SOCIAL SCIENCES Vol. 8, No. 6, June 2018, E-ISSN: 2222-6990 @ 2018 HRMARS

items in the established model, interview methods and pre and post tests. However, the researchers took steps using the Fuzzy Delphi approach.

In expert selection, Adler and Ziglio (1996) suggest that the number of appropriate experts in the Delphi method is between 10 and 15 if there is a high level of homogeneity among the experts while the number of non-uniform (heterogeneous) experts. Clayton (1997) states that the number of suitable experts is between 5 to 10 people but the usual "rule of thumb" in the Delphi technique number 10-15 sample is sufficient. Jones and Twiss (1978) suggest that the number of suitable experts in this method is between 10 and 50 people.

However, the researcher will choose 13 experts in this phase based on certain expertise that will evaluate the model that will be developed by the researcher. The Delphi method has no special method in the selection of experts (Kaplan, 1971). The most important aspect in the selection of experts is the impact and quality of the agreement involving the study (Jacob, 1996). However, the selection of experts should be considered to certain criteria. According to Pill (1971), the selection of experts should take into account and need to have expertise and experience in certain areas and be able to contribute views and agreements to the needs of a study.

Table 1. Respondents for Design and Development Phase using FDM

\begin{tabular}{lcccc}
\hline Position & Field's expert & $\begin{array}{c}\text { Working } \\
\text { Experience }\end{array}$ & $\begin{array}{c}\text { Total } \\
\text { Expert }\end{array}$ & Institution \\
\hline Senior Lecturer & TVET & 15 years $>$ & 1 & UTM \\
Deputy Director & TVET & 15 years $>$ & 1 & IPGKPT \\
Senior Officer & TVET & 15 years $>$ & 3 & BPTV \\
Senior Lecturer & Trading & 15 years $>$ & 4 & Polytechnic \\
IPG's Lecturer & TVET & 15 years $>$ & 1 & IPGKPT \\
Vocational & Technical & 15 years $>$ & 3 & Vocational \\
College's & & & & College \\
Lecturer & & TOTAL EXPERTS $=$ & 13 & \\
\hline & & & \\
& &
\end{tabular}

\section{Instruments}

The instrument for Fuzzy Delphi was based on the literature riview. Based on Skulmowski, Hartman \& Krahn (2007), the formulation of questionnaire elements by researchers can be based on literature review, pilot studies and experiences. According to Ridhwan, Saedah, Zaharah, NurulRabihah \& Ahmad Arifin (2014) in forming a question for Delphi's Fuzzy technique based on the highlights of the study, expert interviews and also through focus group techniques. In addition, according to Okoli and Pawlowski (2004) the creation of items and content elements of a study should be made through the literature review related to the scope of the study. Consequently, researchers use literature highlights and expert interviews in acquiring factors that affect academic dishonesty. After elements and factors have been identified through literature and expert interviews, a set of expert questions is formed using a 7-point scale. The 7-point scale selection chosen is due to the increasingly accurate and precise scale of the data obtained (Ridhuan, Saedah, Zaharah, Nurulrabihah and Ahmad Arifin 2014). To facilitate the expert to answer the questionnaire, the researcher placed a scale of 1 to 7 to replace the Fuzzy value as shown in Table 4 for the following 7 linguistic scales: 
INTERNATIONAL JOURNAL OF ACADEMIC RESEARCH IN BUSINESS AND SOCIAL SCIENCES

Vol. 8, No. 6, June 2018, E-ISSN: 2222-6990 @ 2018 HRMARS

Table 2. Level of agreements and Fuzzy scale (7 points)

\begin{tabular}{|l|c|}
\hline \multicolumn{1}{|c|}{ Linguistic variables } & Fuzzy Scale \\
\hline Extreme Strongly disagree & $(0.0,0.0,0.1)$ \\
\hline Strongly disagree & $(0.0,0.1,0.3)$ \\
\hline Disagree & $(0.1,0.3,0.5)$ \\
\hline Not sure & $(0.3,0.5,0.7)$ \\
\hline Agree & $(0.5,0.7,0.9)$ \\
\hline Strongly agree & $(0.7,0.9,1.0)$ \\
\hline Extreme strongly agree & $(0.9,1.0,1.0)$ \\
\hline
\end{tabular}

Sources: (Ridhuan et al., 2014; Chang, Hsu \& Chang, 2011)

\section{The Process of Data Collection and Analysis}

FDM implementation steps

1. Selection of experts:

In the selection of experts, for this study a total of 13 experts will be used as described in the previous chapter. The number of experts invited to determine the importance of the evaluation criteria against the variables to be measured by using the linguistic variables. The process of obtaining information and data depends on the researcher's own initiative. Among the methods that researchers can use are: i) conduct scientific seminars or workshops and invite involved experts, ii) meet face-to-face with identified experts, and, iii) online dissemination such as via e-mail to experts who are known to be proficient in any field the researcher wants.

But for this phase, researchers will choose to meet face-to-face with selected and identified experts to facilitate the process of discussion and explanation of the issues that may exist in the item and so on.

2. Determination of linguistic variables:

This process involves the conversion process of all linguistic variables into triangular fuzzy numbers. According to Hsieh, Lu and Tzeng (2004), this step also involves the conversion of linguistic variables to the addition of fuzzy numbers. The linguistic scale resembles likert scale used in other studies but, coupled with fuzzy numbering based on fuzzy triangular triangles. Each response received 3 fuzzy values representing expert opinion (fuzziness expert opinion). Three values as shown Figure 3.2: 


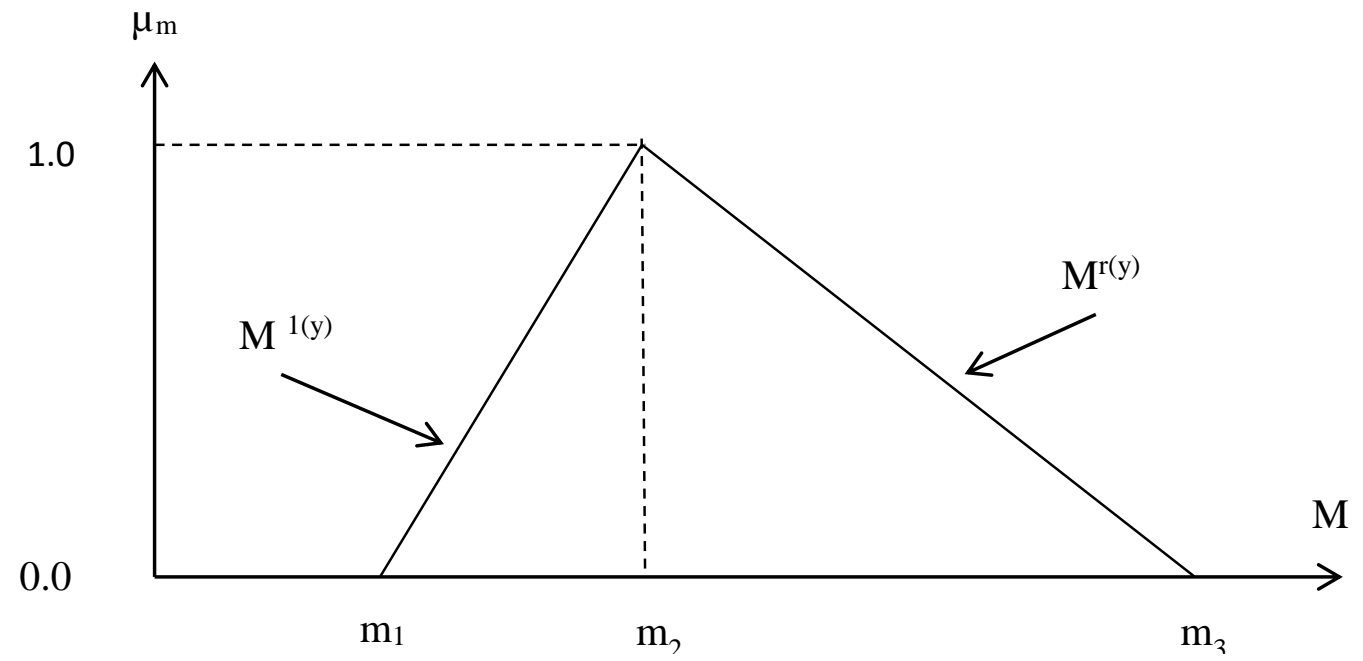

3. Step 3:

Next, after the researcher receives a response from the selected specialist, the researcher needs to convert all the likert scale to the Fuzzy scale. This process is known as the everage responses of each fuzzy number (Benitez, Martin, and Roman 2007). This process is based on the formula:

$$
M=\frac{\sum_{i}^{n}=1 m i}{n}
$$

\section{Step 4: The process of identifying the value of Treshold "d"}

The process identifies the value of Treshold " $d$ ". Threshold value is very important in the process of identifying the level of agreement among experts (Thomaidis, Nikitakos and Dounias 2006). The distance for each fuzzy number $m=(m 1, m 2, m 3)$ and $n=(m 1, m 2, m 3)$ is calculated using the formula:

$$
d(\tilde{m}, \tilde{n})=\sqrt{\frac{1}{3}\left[\left(m_{1}-n_{1}\right)^{2}+\left(m_{2}-n_{2}\right)^{2}+\left(m_{3}-n_{3}\right)^{2}\right]} .
$$

The threshold value is very important in determining the agreement between experts. Cheng and Lin (2002) argue, if the threshold value is less than or equal to 0.2, then it is considered an expert agreement has been reached. While the whole agreement (group consensus) should exceed the $75 \%$ agreement for each item, otherwise the second round should be implemented.

5. Step 5: Identify the alpha level of aggregate of fuzzy assessments 
INTERNATIONAL JOURNAL OF ACADEMIC RESEARCH IN BUSINESS AND SOCIAL SCIENCES

Vol. 8, No. 6, June 2018, E-ISSN: 2222-6990 C 2018 HRMARS

Identify the level of alpha aggregate of fuzzy assessment after expert agreement is obtained by adding fuzzy numbers for each item (Ridhuan 2013). The calculation and determination of fuzzy values is by using the formula: $A_{\max }=/(m 1+2 m 2+m 3)$.

$$
\begin{aligned}
& \widetilde{A}=\left[\begin{array}{c}
\widetilde{A}_{1} \\
\widetilde{A}_{2} \\
\vdots \\
\vdots \\
\widetilde{A}_{m}
\end{array}\right] \text { where } \widetilde{A}=r_{i 1} \times w_{1}+r_{i 2} \times w_{2}+\ldots \ldots \ldots r_{i n} \times w_{n} \\
& i=1,2, \ldots \ldots \ldots, \mathrm{m}
\end{aligned}
$$

6. Step 6: The next step is phase difuzzication process:

The Last Step is a difuzzication phase. This process uses the Amax $=/(a 1+2 a m+a 3)$ formula. If the researcher uses Average Fuzzy Numbers or average response, the score number is the number that is in the range 0 to 1 (Ridhuan et al., 2014).

\section{Step 7: The process of ranking:}

Fortemps and Roubens (1996) explains the process of ranking or sub-phases for the model. The positioning process is by selecting the model element based on defuzzication value based on expert agreement where the highest value element is determined by the most important position in the model.

\section{Results}

Based on literature analysis (refer to table 1) and expert interviews (refer to table 2) listed the factors affecting the transfer of training among vocational colleges in Malaysia: 
INTERNATIONAL JOURNAL OF ACADEMIC RESEARCH IN BUSINESS AND SOCIAL SCIENCES

Vol. 8, No. 6, June 2018, E-ISSN: 2222-6990 (C) 2018 HRMARS

Table 3: Factors affecting the transfer of training among Vocational College teachers

\begin{tabular}{|l|l|}
\hline \multirow{2}{*}{ No } & \multicolumn{1}{|c|}{ Items/Element } \\
\cline { 2 - 3 } & Training Designs \\
\hline 1 & $\begin{array}{l}\text { Creating a real working environment in training facilitates trainers to understand the work } \\
\text { process. }\end{array}$ \\
\hline 2 & Instructors have time constraints to explain in detail about a work process at the training center. \\
\hline 3 & Employers need to give assignments that allow teachers to practice what they are learning. \\
\hline 4 & $\begin{array}{l}\text { Employers need to provide the resources needed to enable teachers to practice what they have } \\
\text { learned. }\end{array}$ \\
\hline 5 & Training content should be in line with actual work processes. \\
\hline 6 & $\begin{array}{l}\text { Feedback from instructors who have undergone training is necessary to assist instructors to } \\
\text { acquire new technology-related information in the industry. }\end{array}$ \\
\hline 7 & $\begin{array}{l}\text { Existing experience of instructors is needed to help new faculty, understand the work process } \\
\text { more easily. }\end{array}$ \\
\hline 8 & $\begin{array}{l}\text { The equipment provided by the training center should be complete for instructors to perform } \\
\text { their duties. }\end{array}$ \\
\hline 9 & The training program provided should help trainers improve their performance. \\
\hline 10 & Collaboration from industry is necessary to introduce new technologies to trainers. \\
\hline 11 & $\begin{array}{l}\text { Updates from industries that involve new technologies need to ensure that what is being } \\
\text { learned according to current industry needs. }\end{array}$ \\
\hline 12 & $\begin{array}{l}\text { The addition of the syllabus performed by the training center is necessary to improve the skill } \\
\text { of the trainer. The work done should give priority to safety. }\end{array}$ \\
\hline 13 & The work done should give priority to safety. \\
\hline 14 & More opportunities come to work if teachers practice what they have learned. \\
\hline
\end{tabular}


INTERNATIONAL JOURNAL OF ACADEMIC RESEARCH IN BUSINESS AND SOCIAL SCIENCES

Vol. 8, No. 6, June 2018, E-ISSN: 2222-6990 @ 2018 HRMARS

\section{An Expert Consensus On Factors Affecting The Transfer Of Training}

Table 4: Threshold value (d), percentage of expert consensus, defuzzication and ranking

\begin{tabular}{|c|c|c|c|c|c|c|c|c|c|c|c|c|c|c|}
\hline & \multicolumn{14}{|c|}{ ITEMS } \\
\hline & 1 & 2 & 3 & 4 & 5 & 6 & 7 & 8 & 9 & 10 & 11 & 12 & 13 & 14 \\
\hline \multirow[b]{2}{*}{ Expert 1} & 0.0 & 0.7 & 0.1 & 0.0 & 0.0 & 0.0 & 0.0 & 0.0 & 0.0 & 0.0 & 0.0 & 0.2 & 0.6 & 0.5 \\
\hline & 2 & 4 & 6 & 7 & 8 & 5 & 8 & 8 & 7 & 5 & 7 & 0 & 9 & 6 \\
\hline \multirow[b]{2}{*}{ Expert 2} & 0.0 & 0.7 & 0.1 & 0.0 & 0.0 & 0.0 & 0.0 & 0.0 & 0.0 & 0.0 & 0.0 & 0.4 & 0.6 & 0.5 \\
\hline & 3 & 4 & 6 & 7 & 8 & 7 & 8 & 8 & 7 & 5 & 7 & 9 & 9 & 6 \\
\hline \multirow[b]{2}{*}{ Expert 3} & 0.0 & 0.2 & 0.1 & 0.0 & 0.0 & 0.0 & 0.0 & 0.0 & 0.0 & 0.0 & 0.0 & 0.4 & 0.6 & 0.5 \\
\hline & 2 & 4 & 6 & 7 & 8 & 7 & 8 & 8 & 7 & 5 & 7 & 9 & 9 & 6 \\
\hline \multirow[b]{2}{*}{ Expert 4} & 0.1 & 0.4 & 0.2 & 0.0 & 0.0 & 0.1 & 0.0 & 0.0 & 0.1 & 0.1 & 0.0 & 0.2 & 0.1 & 0.0 \\
\hline & 3 & 4 & 3 & 7 & 8 & 4 & 8 & 8 & 3 & 1 & 7 & 0 & 7 & 7 \\
\hline \multirow[b]{2}{*}{ Expert 5} & 0.0 & 0.2 & 0.8 & 0.0 & 0.0 & 0.0 & 0.0 & 0.0 & 0.3 & 0.0 & 0.0 & 0.2 & 0.1 & 0.0 \\
\hline & 2 & 4 & 3 & 9 & 8 & 7 & 8 & 8 & 2 & 5 & 9 & 0 & 7 & 7 \\
\hline \multirow[b]{2}{*}{ Expert 6} & 0.0 & 0.2 & 0.1 & 0.0 & 0.0 & 0.0 & 0.0 & 0.0 & 0.0 & 0.0 & 0.9 & 0.9 & 0.2 & 0.0 \\
\hline & 2 & 4 & 6 & 7 & 8 & 7 & 8 & 8 & 8 & 5 & 9 & 6 & 9 & 7 \\
\hline \multirow[b]{2}{*}{ Expert 7} & 0.0 & 0.1 & 0.0 & 0.0 & 0.0 & 0.1 & 0.0 & 0.0 & 0.0 & 0.0 & 0.0 & 0.0 & 0.2 & 0.3 \\
\hline & 2 & 3 & 5 & 7 & 8 & 4 & 8 & 8 & 7 & 5 & 7 & 8 & 9 & 0 \\
\hline \multirow[b]{2}{*}{ Expert 8} & 0.0 & 0.2 & 0.0 & 0.0 & 0.0 & 0.0 & 0.0 & 0.0 & 0.0 & 0.0 & 0.0 & 0.0 & 0.2 & 0.4 \\
\hline & 2 & 4 & 5 & 7 & 8 & 7 & 8 & 8 & 7 & 5 & 7 & 8 & 9 & 3 \\
\hline \multirow[b]{2}{*}{ Expert 9} & 0.0 & 0.1 & 0.0 & 0.0 & 0.0 & 0.0 & 0.0 & 0.0 & 0.0 & 0.0 & 0.0 & 0.2 & 0.2 & 0.4 \\
\hline & 2 & 3 & 5 & 7 & 8 & 7 & 8 & 8 & 7 & 5 & 7 & 0 & 9 & 3 \\
\hline \multirow[b]{2}{*}{ Expert 10} & 0.1 & 0.2 & 0.0 & 0.3 & 0.0 & 0.1 & 0.0 & 0.3 & 0.0 & 0.1 & 0.0 & 0.2 & 0.1 & 0.0 \\
\hline & 3 & 4 & 5 & 2 & 8 & 4 & 8 & 2 & 9 & 1 & 9 & 0 & 2 & 7 \\
\hline \multirow[b]{2}{*}{ Expert 11} & 0.0 & 0.2 & 0.1 & 0.0 & 0.0 & 0.0 & 0.0 & 0.0 & 0.0 & 0.1 & 0.3 & 0.2 & 0.2 & 0.2 \\
\hline & 2 & 4 & 6 & 7 & 8 & 7 & 7 & 8 & 7 & 1 & 3 & 0 & 9 & 5 \\
\hline \multirow[b]{2}{*}{ Expert 12} & 0.0 & 0.1 & 0.1 & 0.0 & 0.0 & 0.0 & 0.0 & 0.0 & 0.0 & 0.0 & 0.0 & 0.2 & 0.2 & 0.3 \\
\hline & 2 & 3 & 6 & 7 & 8 & 7 & 8 & 8 & 7 & 5 & 7 & 0 & 9 & 0 \\
\hline \multirow[b]{2}{*}{ Expert 13} & 0.0 & 0.1 & 0.0 & 0.3 & 0.3 & 0.2 & 0.0 & 0.0 & 0.0 & 0.1 & 0.0 & 0.0 & 0.1 & 0.3 \\
\hline & 2 & 3 & 5 & 2 & 2 & 2 & 8 & 8 & 9 & 1 & 9 & 8 & 7 & 0 \\
\hline \multirow{2}{*}{$\begin{array}{l}\text { D Value } \\
\text { each } \\
\text { elements }\end{array}$} & 0.0 & 0.3 & 0.1 & 0.1 & 0.1 & 0.1 & 0.0 & 0.1 & 0.1 & 0.0 & 0.1 & 0.2 & 0.3 & 0.3 \\
\hline & 4 & 0 & 7 & 1 & 0 & 0 & 8 & 0 & 0 & 7 & 6 & 7 & 4 & 0 \\
\hline $\begin{array}{l}\text { D Value } \\
\text { for } \\
\text { Construct }\end{array}$ & \multicolumn{14}{|c|}{0.16} \\
\hline $\begin{array}{l}\text { Consensus } \\
\text { percentag } \\
\text { e }\end{array}$ & \multicolumn{14}{|c|}{0.75} \\
\hline \multirow{2}{*}{$\begin{array}{l}\text { Percentag } \\
\text { e item } d< \\
0.2\end{array}$} & 1.0 & 0.3 & 0.8 & 0.9 & 0.9 & 0.8 & 1.0 & 0.9 & 0.9 & 1.0 & 0.8 & 0.3 & 0.3 & 0.3 \\
\hline & 0 & 8 & 5 & 2 & 2 & 5 & 0 & 2 & 2 & 0 & 5 & 1 & 1 & 1 \\
\hline
\end{tabular}


INTERNATIONAL JOURNAL OF ACADEMIC RESEARCH IN BUSINESS AND SOCIAL SCIENCES

Vol. 8, No. 6, June 2018, E-ISSN: 2222-6990 @ 2018 HRMARS

\begin{tabular}{|l|l|l|l|l|l|l|l|l|l|l|l|l|l|l|}
\hline $\begin{array}{l}\text { Defuzzicat } \\
\text { ion (fuzzy } \\
\text { evaluation } \\
\text { 1 }\end{array}$ & $\begin{array}{l}12 . \\
37\end{array}$ & $\begin{array}{l}10 . \\
37\end{array}$ & $\begin{array}{l}11 . \\
13\end{array}$ & $\begin{array}{l}11 . \\
13\end{array}$ & $\begin{array}{l}11 . \\
93\end{array}$ & $\begin{array}{l}11 . \\
90\end{array}$ & $\begin{array}{l}12 . \\
17\end{array}$ & $\begin{array}{l}11 . \\
90\end{array}$ & $\begin{array}{l}11 . \\
90\end{array}$ & $\begin{array}{l}12 . \\
00\end{array}$ & $\begin{array}{l}12 . \\
17\end{array}$ & $\begin{array}{l}11 . \\
23\end{array}$ & $\begin{array}{l}10 . \\
00\end{array}$ & $\begin{array}{c}9.1 \\
4\end{array}$ \\
\hline $\begin{array}{l}\text { Defuzzicat } \\
\text { ion } \\
\text { (average } \\
\text { of fuzzy } \\
\text { response) }\end{array}$ & $\begin{array}{l}0.9 \\
5\end{array}$ & $\begin{array}{l}0.8 \\
0\end{array}$ & $\begin{array}{l}0.8 \\
6\end{array}$ & $\begin{array}{l}0.8 \\
6\end{array}$ & $\begin{array}{l}0.9 \\
2\end{array}$ & $\begin{array}{l}0.9 \\
2\end{array}$ & $\begin{array}{l}0.9 \\
4\end{array}$ & $\begin{array}{l}0.9 \\
2\end{array}$ & $\begin{array}{l}0.9 \\
2\end{array}$ & $\begin{array}{l}0.9 \\
2\end{array}$ & $\begin{array}{l}0.9 \\
4\end{array}$ & $\begin{array}{l}0.8 \\
3\end{array}$ & $\begin{array}{l}0.8 \\
1\end{array}$ & $\begin{array}{l}0.7 \\
2\end{array}$ \\
\hline Ranking & 1 & 8 & 7 & 7 & 4 & 5 & 2 & 5 & 5 & 3 & 2 & 6 & 9 & 10 \\
\hline
\end{tabular}

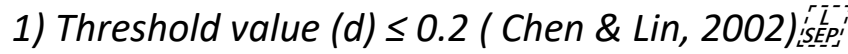

2) Expert Consenses Percentage $\geq 75 \%$ (Tang \& Wu, 2010) SERE?

3) Alpha value-Cut for each items must exceed $\alpha=0.5$ (Bojdanova , 2006)

Based on table 4 the threshold values are blackened above the threshold value of 0.2 (> $0.2)$. This means that there is an uneven expert opinion and does not reach consensus on certain items. However, the overall value of $d$ constructs shows $0.159(<0.2)$ According to Cheng and Lin (2002) and Chang, Hsu and Chang (2011) if the average threshold value (d) is less than 0.2 , the item has reached an expert agreement. Whilst this percentage of the overall agreement is in the $75 \%$ consent value of more than (75\%), it means meeting an expert agreement on the item. According to Chang, Hsu and Chang (2011) the percentage of the agreement should exceed $75 \%$. In addition, all Alpha-Cut defuzzication (average of fuzzy response) exceeds 0.5. According to Tang and $\mathrm{Wu},(2010)$ and Bodjanova (2006) alpha cut values should exceed 0.5. This shows the training design items) has got the agreement of the experts involved. The agreed items are sorted according to the ranking as shown in table 5 . However there are 3 items dropped because they did not get the expert agreement ie $D$ value per item above 0.2 (items 2, 12, 13 and 14).

Overall, all items have been awarded with an agreement with a good consent value and fulfilled the set requirements. The results of the analysis on consensus and expert consensus show that the value of the agreement is at a good level. Therefore, this study has successfully answered the question of the study where the results of the analysis show that there is an expert agreement in describing the factors that influence the transfer of training among instructors. 
INTERNATIONAL JOURNAL OF ACADEMIC RESEARCH IN BUSINESS AND SOCIAL SCIENCES

Vol. 8, No. 6, June 2018, E-ISSN: 2222-6990 @ 2018 HRMARS

Table 5: Training design factors affecting training transfers

\begin{tabular}{|c|c|c|}
\hline \multirow{2}{*}{ No } & Items/Elements & \multirow[b]{2}{*}{ Ranking } \\
\hline & Training Designs & \\
\hline 1 & $\begin{array}{l}\text { Creating a real working environment in training facilitates trainers to } \\
\text { understand the work process. }\end{array}$ & 1 \\
\hline 2 & $\begin{array}{l}\text { Instructors have time constraints to explain in detail about a work } \\
\text { process at the training center. }\end{array}$ & 8 \\
\hline 3 & $\begin{array}{l}\text { Employers need to give assignments that allow teachers to practice what } \\
\text { they are learning. }\end{array}$ & 7 \\
\hline 4 & $\begin{array}{l}\text { Employers need to provide the resources needed to enable teachers to } \\
\text { practice what they have learned. }\end{array}$ & 7 \\
\hline 5 & Training content should be in line with actual work processes. & 4 \\
\hline 6 & $\begin{array}{l}\text { Feedback from instructors who have undergone training is necessary to } \\
\text { assist instructors to acquire new technology-related information in the } \\
\text { industry. }\end{array}$ & 5 \\
\hline 7 & $\begin{array}{l}\text { Existing experience of instructors is needed to help new faculty, } \\
\text { understand the work process more easily. }\end{array}$ & 2 \\
\hline 8 & $\begin{array}{l}\text { The equipment provided by the training center should be complete for } \\
\text { instructors to perform their duties. }\end{array}$ & 5 \\
\hline 9 & $\begin{array}{l}\text { The training program provided should help trainers improve their } \\
\text { performance. }\end{array}$ & 5 \\
\hline 10 & $\begin{array}{l}\text { Collaboration from industry is necessary to introduce new technologies } \\
\text { to trainers. }\end{array}$ & 3 \\
\hline 11 & $\begin{array}{l}\text { Updates from industries that involve new technologies need to ensure } \\
\text { that what is being learned according to current industry needs. }\end{array}$ & 2 \\
\hline 12 & $\begin{array}{l}\text { The addition of the syllabus performed by the training center is necessary } \\
\text { to improve the skill of the trainer. }\end{array}$ & 6 \\
\hline 13 & The work done should give priority to safety. & 9 \\
\hline 14 & $\begin{array}{l}\text { More opportunities come to work if teachers practice what they have } \\
\text { learned. }\end{array}$ & 10 \\
\hline
\end{tabular}

Based on table 5, experts specifically agree that training design aspects are the most important aspect of the training transfer model. The priority aspect based on expert agreement is "Creating a real working environment in training facilitates trainers to understand the work process". The second aspect of an expert agreement is "The existing experience of instructors is needed to assist new instructors, understand work processes more easily", and "Updates from industries that involve new technologies are necessary to ensure that what is being learned according to current industry needs". The third item is "Cooperation from industry is necessary to introduce new technologies to teaching staff". The fourth item that got the deal was "The content of the training needs to be in line with the actual work process" followed by "Feedback from instructors who have undergone the necessary training to help trainers obtain information on new technology in the industry", "Equipment provided by the training center need to be complete for instructors to carry out tasks ", and" The training program provided should help trainers improve their performance". While the sixth aspect is the item 
INTERNATIONAL JOURNAL OF ACADEMIC RESEARCH IN BUSINESS AND SOCIAL SCIENCES Vol. 8, No. 6, June 2018, E-ISSN: 2222-6990 @ 2018 HRMARS

"The addition of the syllabus performed by the training center is necessary to improve the skill of the instructors". For the seventh aspect, "The employer needs to give an assignment that allows the instructor to practice what is learned", and "Employers need to provide the resources needed to enable teachers to practice what they have learned". The eighth aspect of the course is "Teachers experience time constraints to explain in detail about a work process at the training center". The next aspect is "The work done is to prioritize the safety of work". Last but not least, the tenth aspect is "More and more chances of dating work if teachers practice what they have learned". All of these items become the basis in the training design.

\section{Discussion and Conclusion}

After reviewing the results of the study, it can be summarized and suggested some aspects as a guide. Emphasis on aspects of training design. In the context of training, the design aspect of the exercise plays a significant role and gives a good influence on the transfer of training of instructors. This is in line with the needs of the ministries concerned with the quality of teaching delivered to trainees to produce quality manpower as well. Additionally, awareness of training is appropriate for the field of teaching staff. This aspect needs to be addressed by educational institutions and policy makers. As explained by the factors that cause this problem to occur there is concern with the awareness of the uniqueness of the field of training given to instructors in the service. In conclusion as a result of the use of FDM, the findings show that there is a good expert agreement on the items that form the basis in the design of the training.

\section{Corresponding Author}

Syamsiah Mokhtar, Faculty of Education, National University of Malaysia, Malaysia ummumunqiz08@gmail.com

\section{References}

Adler, M., \& Ziglio, E. (1996). Gazing into the Oracle: The Delphi method and its application to social policy and public health: Jessica Kingsley Publisher.

Ahmad, A. (2011). Effectiveness of Learning Transfer in National Dual Training System (NDTS). Tesis Ph.D, Faculty of Technical and Vocational Education, Universiti Tun Hussein Onn Malaysia.

Baldwin, T. T. \& Ford, J. K. (1988). Transfer of Training: A Review and Direction for Future Research. Personnel Psychology 41(1): 63-105.

Baldwin, T. T., Ford, J. K. \& Blume, B. D. (2009). Transfer of Training 1988-2008: An Updated Review and Agenda for Future Research. DIm. G. P. Hodgkinson \& J. K. Ford (pnyt.). International Review of Industrial and Organizational Psychology, 24. hlm. 41-71. John Wiley \& Sons, Ltd.

Bates, R., Kauffeld, S. \& Holton III, E. F. (2007). Examining the Factor Structure and Predictive Ability of the German-Version of the Learning Transfer Systems Inventory. Journal of European Industrial Training 31(3): 195-211.

Berliner, R., (2004). The Near Impossibility Of Testing For Teacher Quality Education Policy Studies Laboratory. EPSL-0505-EPRU.

Benitez, J.M., Martin, J.C., \& Roman, C. (2007). Using Fuzzy number for measuring quality of service in the hotel industry. Tourism management, 28(2), 544-555.

Blume, B. D., Ford, J. K., Baldwin, T. T. \& Huang, J. L., (2010). Transfer of Training: A Meta-Analytic Review. Journal of Management 36(4): 1065-1105. 
INTERNATIONAL JOURNAL OF ACADEMIC RESEARCH IN BUSINESS AND SOCIAL SCIENCES

Vol. 8, No. 6, June 2018, E-ISSN: 2222-6990 @ 2018 HRMARS

Burke, L. A. \& Hutchins, H. M. (2007). Training Transfer: An Integrative Literature Review. Human Resource Development Review 6(3): 263-296.

Cheng, C.H., \& Lin, Y. (2002). Evaluating the best main battle tank using fuzzy Decision theory with linguistic criteria evaluation. European Journal of operational research, 142(1), 174-186.

Clayton, M.J. (1997). Delphi: A technique to harness expert opinion for critical decision-making task in education. Educational psychology, 17(4), 373-384

Coetsee, W. J., Eiselen, R. \& Basson, J. (2006). Validation of the Learning Transfer System Inventory in the South African Context (Part 1). SA Journal of Industrial Psychology, 32 (2): 46-55.

Devos, C., Dumay, X., Bonami, M., Bates, R. \& Holton, I. E. (2007). The Learning Transfer System Inventory (Ltsi) Translated into French: Internal Structure and Predictive Validity. International Journal of Training and Development 11(3): 181-199.

Dayang Nailul Munna, A. A. \& Suring, J. C. (2011). The Relationship between Motivation to Transfer, Training Design, Transfer Climate and Transfer of Training. 2010 International Conference on E-business, Management and Economics, hlm. 335-339.

Devos, C., Dumay, X., Bonami, M., Bates, R. \& Holton, I. E. (2007). The Learning Transfer System Inventory (Ltsi) Translated into French: Internal Structure and Predictive Validity. International Journal of Training and Development 11(3): 181-199.

Fortemps, P., \& Reubens, M. (1996). Ranking and defuzzications methods based area compensation. Fuzzy sets and system, 82(3), 319-330.

Hasson, F., Keeney, S.K. \& McKenna, H., (2000). Research Guidelines for the Delphi survey technique. Journal of advanced Nursing, 32(4), 1008-1015.

Holladay, C. L. \& Quinones, M. A. (2003). Practice Variability and Transfer of Training: The Role of Self-Efficacy Generality. Journal of Applied Psychology 88(6): 1094.

Holton, I. E. F. (1996). The Flawed Four-Level Evaluation Model. Human Resource Development Quarterly 7(1): 5-21.

Holton, E. F., Bates, R. A. \& Ruona, W. E. A., (2000). Development of a Generalized Learning Transfer System Inventory. Human Resource Development Quarterly 11(4): 333-360.

Hsieh, T.Y., Lu, S.T., Tzeng, G.H., (2004). Fuzzy MCDM approach for planning and design tenders selection in public office building. International journal of project management, 22(7), 573-584.

Hutchins, H. M. (2009). In the Trainer's Voice: A Study of Training Transfer Practices. Performance Improvement Quarterly 22(1): 69-93.

Jacobs, J.M., (1996). Essential assessment criteria for physical education teacher education programme: A Delphi study (tesis yang tidak diterbitkan). West Virginia University, Morgantown.

Jones, H., \& Twiss, B.L., (1978). Fofecasting technology of planning decisions. New York: McMillan

Kaplan, L.M., (1971). The use of Delphi method in organizational communication: A case study. Columbus: Ohio State University.

Lim, D. H. \& Morris, M. L., (2006). Influence of Trainee Characteristics, Instructional Satisfaction, and Organizational Climate on Perceived Learning and Training Transfer. Human Resource Development Quarterly 17(1): 85-115.

Machin, M. A. \& Fogarty, G. J., (2004). Assessing the Antecedents of Transfer Intentions in a Training Context. International Journal of Training and Development 8(3): 222-236.

Idris, N. (2010). Penyelidikan dalam Pendidikan. Kuala Lumpur: McGraww Hill Malaysia.

Pill, J., (1971). The Delphi method: substance, context, a critique and an notated bibliography. Socioeconomic Planning Science, 57-71. 
INTERNATIONAL JOURNAL OF ACADEMIC RESEARCH IN BUSINESS AND SOCIAL SCIENCES

Vol. 8, No. 6, June 2018, E-ISSN: 2222-6990 @ 2018 HRMARS

Baharim, S. (2008). The Influence of Knowledge Sharing on Motivation to Transfer Training: A Malaysian Public Sector Context. Tesis PhD, School of Management Faculty of Business and Law Victoria University Melbourne.

Thomaidis, N.S., Nikitakos, N., \& Dounias, G.D., (2006). The evaluation of informations technology projects: A Fuzzy multicriteria decision-making approach. International journal of information \& Decision Making, 5(01), 89-122.

Velada, R., Caetano, A., Michel, J. W., Lyons, B. D. \& Kavanagh, M. J., (2007). The Effects of Training Design, Individual Characteristics and Work Environment on Transfer of Training. International Journal of Training and Development 11(4): 282-294. 